\title{
Characterization of a Component of the Yeast Secretion Machinery: Identification of the SEC18 Gene Product
}

\author{
KURT A. EAKLE, ${ }^{1}$ MITCHELL BERNSTEIN,${ }^{2}+$ AND SCOTT D. EMR ${ }^{1 *}$ \\ Division of Biology, 147-75, California Institute of Technology, Pasadena, California $91125,{ }^{1}$ and \\ Department of Biochemistry, University of California, Berkeley, California $94720^{2}$
}

Received 20 May 1988/Accepted 27 June 1988

\begin{abstract}
$S E C 18$ gene function is required for secretory protein transport between the endoplasmic reticulum (ER) and the Golgi complex. We cloned the $S E C 18$ gene by complementation of the sec18-1 mutation. Gene disruption has shown that $S E C 18$ is essential for yeast cell growth. Sequence analysis of the gene revealed a 2,271-base-pair open reading frame which could code for a protein of 83.9 kilodaltons. The predicted protein sequence showed no significant similarity to other known protein sequences. In vitro transcription and translation of $S E C 18$ led to the synthesis of two proteins of approximately 84 and 82 kilodaltons. Antisera raised against a Sec18- $\beta$-galactosidase fusion protein also detected two proteins (collectively referred to as Sec18p) in extracts of ${ }^{35} \mathrm{~S}$-labeled yeast cells identical in size to those seen by in vitro translation. Mapping of the $5^{\prime}$ end of the $S E C 18$ mRNA revealed only one major start site for transcription, which indicates that the multiple forms of Sec18p do not arise from mRNAs with different 5 ' ends. Results of pulse-chase experiments indicated that the two forms of Sec18p are not the result of posttranslational processing. We suggest that translation initiating at different in-frame AUG start codons is likely to account for the presence of two forms of Sec18p. Hydrophobicity analysis indicated that the proteins were hydrophilic in nature and lacked any region that would be predicted to serve as a signal sequence or transmembrane anchor. Although potential sites for $\mathrm{N}$-linked glycosylation were present in the Sec18p sequence, the sizes of the in vivo SEC18 gene products were unaffected by the drug tunicamycin, indicating that Sec18p does not enter the secretory pathway. These results suggest that Sec18p resides in the cell cytoplasm. While preliminary cell fractionation studies showed that Sec18p is not associated with the ER or Golgi complex, association with a $100,000 \times g$ pellet fraction was observed. This suggests that Sec18p may bind transiently to small vesicles such as those presumed to participate in secretory protein transport between ER and the Golgi complex.
\end{abstract}

The temperature-conditional yeast sec mutants define a set of functions required for secretory protein transport $(20$, $25)$. Nine sec genes, including sec 18 , have been shown to cause a block in the transport of secretory proteins between the yeast endoplasmic reticulum (ER) and the Golgi complex $(7,19)$. In secl8-1 mutant yeast cells, secretory protein traffic is blocked at the level of the ER on a shift to the nonpermissive growth temperature $\left(37^{\circ} \mathrm{C}\right)$. This is true for both secreted enzymes, such as invertase, and vacuolar proteases, like carboxypeptidase Y (CPY), which use the secretory pathway for intracellular localization (28). In sec 18 mutant cells, ER function per se is not impaired. Protein translocation across the ER membrane continues at the nonpermissive temperature, as do secretory protein processing activities such as signal sequence cleavage and core oligosaccharide addition. However, protein modifications characteristic of the Golgi complex, such as the addition of outer chain mannose residues, are not observed on the accumulated secretory proteins $(7,19)$. Electron microscopy has shown that sec18 mutant cells accumulate exaggerated forms of the $\operatorname{ER}(19,25)$. When secl8 mutant cells are returned to the permissive temperature $\left(23^{\circ} \mathrm{C}\right)$, accumulated secretory proteins undergo transport and processing through the remainder of the secretory pathway (20). Accumulated invertase is released at the cell surface as the normal, active, highly glycosylated enzyme. Together, the specificity of the sec18-1 defect as well as its reversibility indicate that the

\footnotetext{
* Corresponding author.

$\dagger$ Present address: Department of Biology, Princeton University, Princeton, NJ 08544.
}

sec 18 mutant accumulates an authentic intermediate in the protein secretion pathway. Because interorganelle traffic between secretory compartments likely occurs via vesicle carriers, the $S E C 18$ gene is presumed to encode a function that is involved in either the selective packaging of secretory proteins into carrier vesicles or the transport and fusion of such vesicles with the correct Golgi complex target membrane.

We report the cloning and sequencing of the SEC18 gene. In addition, we characterized both the mRNA and two protein products (referred to collectively as Sec18p) encoded by this gene. Together, our observations suggest that Sec18p acts on the vesicle carriers that shuttle membrane and protein between ER and Golgi complex compartments.

\section{MATERIALS AND METHODS}

Strains. Escherichia coli Mc1061 $\left[\mathrm{F}^{-}\right.$araDl39 $\Delta($ araABOIC-leu $7679 \Delta$ lacX74 galU galK rpsL hsdR] (3) was used for cloning and fusion protein production, and JM101 was used for M13 phage growth for sequencing. Saccharomyces cerevisiae strains used were SEY2101 (MATa ura3-52 leu2-3,112 suc2- 49 ade2-1) (6), SEY5186

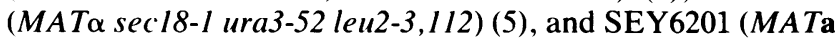

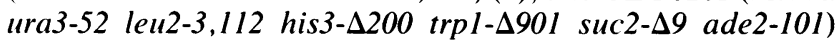
(this study). Strains were grown in standard medium preparations $(16,27)$.

Materials. Restriction enzymes, T4 DNA ligase, Bal 31 nuclease, mung bean nuclease, and 5-bromo-4-chloro-3indolyl- $\beta$-D-galactoside (Xgal) were purchased from either New England BioLabs, Inc. (Beverly, Mass.) or Bethesda Research Laboratories (Gaithersburg, Md.) and were used 
as recommended by the suppliers. Deoxy- and dideoxynucleotides were purchased from Pharmacia Fine Chemicals (Piscataway, N.J.). Universal sequencing primer was a gift from M. Simon. $\left[{ }^{32} \mathrm{P}\right] \mathrm{dATP},\left[\alpha-\right.$ thio $\left.-{ }^{35} \mathrm{~S}\right] \mathrm{dATP}, \mathrm{Na}^{35} \mathrm{SO}_{4}$, and Trans ${ }^{35} \mathrm{~S}$ label (a hydrolysate of $E$. coli grown in ${ }^{35} \mathrm{SO}_{4}$ containing $\sim 70 \%\left[{ }^{35} \mathrm{~S}\right]$ methionine and $20 \%\left[{ }^{35} \mathrm{~S}\right]$ cysteine) were purchased from ICN Biochemicals (Irvine, Calif.). GeneScreen was purchased from Dupont, NEN Research Products (Boston, Mass.). Sodium dodecyl sulfate (SDS)polyacrylamide gel electrophoresis (PAGE) supplies and Western blot reagents (horseradish peroxidase [HRP] system) were from Bio-Rad Laboratories (Richmond, Calif.). The RNA cap analog $\left[\mathrm{m}^{7} \mathrm{G}\left(5^{\prime}\right) \mathrm{ppp}\left(5^{\prime}\right) \mathrm{G}\right]$, ribonucleotides, and yeast translation extracts were gifts from E. Greyhack. SP6 RNA polymerase and RNasin were from Promega Biotech. Oxylyticase was purchased from Enzogenetics (Corvallis, Oreg.). Antiserum against $\beta$-galactosidase was a gift from T. Silhavy. Antiserum against the $\beta$ subunit of mitochondrial $F_{1}$-ATPase was a gift from M. Douglas. Antiserum against CPY was from Klionsky et al. (10).

Recombinant DNA constructions. Preparation of DNA, restriction digestions, agarose gel electrophoresis, and cloning of DNA fragments were done as described previously (14).

DNA sequencing. DNA sequencing was done by standard dideoxy chain termination methods (24) by using $\mathrm{Bal} 31$ deletion subclones of SEC18 in M13mp19. DNA and protein sequences were compiled and analyzed with computer programs written by $K$. Eakle (unpublished data). Homology searches of the National Biomedical Research Foundation Protein Identification Resource data base were done on BIONET by using the XFASTP program (13).

Antisera production. SEC18-lacZ fusions were generated by cloning $\mathrm{Bal} 31$ nuclease digestions of the 3.0-kilobase (kb) BamHI-HindIII fragment into SmaI-cut pORF5. Clones were screened for overproduction of $\beta$-galactosidase activity on ampicillin-containing plates with Xgal. Plasmid DNA was prepared from candidate clones and checked for SEC18 inserts by restriction mapping. Whole-cell extracts of $E$. coli with candidate plasmids were run on SDS-polyacrylamide gels (11) and evaluated by both Western blotting (30) with primary antisera against $\beta$-galactosidase (visualized by the HRP color reaction system) and staining with Coomassie blue to identify fusion protein bands and to estimate the extent of overproduction.

Fusion proteins were purified by growing $E$. coli with the fusion construction pORF18-40 to the stationary phase. Cells $\left(250 \mathrm{OD}_{600}\right.$ units; $1 \mathrm{OD}_{600}$ unit of cells equals the cells in $1 \mathrm{ml}$ of a culture grown to an optical density at $600 \mathrm{~nm}$ of 1.0) were pelleted and suspended at $10 \mathrm{OD}_{600}$ units per $\mathrm{ml}$ in $50 \mathrm{mM}$ Tris (pH 8.0)-10 mM EDTA-10 mM dithiothreitol. Cells were lysed with a French press and spun at 6,000 $\times g$ for $20 \mathrm{~min}$ at $4^{\circ} \mathrm{C}$ in a rotor (JA-20), and the supernatant was spun at $170,000 \times g$ for $30 \mathrm{~min}$ at $15^{\circ} \mathrm{C}$ in a rotor (Ti70.1). Membrane pellets were suspended in a small volume of buffer, and samples of the fractions were assayed for $\beta$ galactosidase activity at appropriate dilutions (16). Greater than $50 \%$ of the total $\beta$-galactosidase activity of the fusion proteins was associated with the membrane pellet, which yielded the equivalent of 2 to $3 \mathrm{mg}$ of $\beta$-galactosidase activity. The largest fusion band was fragment purified from 5\% SDS-polyacrylamide preparative gels that were stained with Coomassie blue. Commercially available $\beta$-galactosidase was also run on the preparative gels and was used to estimate the amount of fusion protein recovered. Fusion bands were homogenized, dialyzed against phosphate-buff- ered saline, and mixed with an equal volume of $1 \%$ agarose in phosphate-buffered saline. Approximately $50 \mu \mathrm{g}$ of fusion protein was injected subcutaneously into young New Zealand White male rabbits weekly for 4 weeks, and then once every 2 weeks for 4 months. Antisera were initially evaluated for their ability to react in a Western blot procedure to the Sec18- $\beta$-galactosidase fusion protein that was present in a whole-cell SDS-polyacrylamide gel extract of $E$. coli Mc1061 transformed with the pORF18-40 fusion construct. Attempts at identifying the yeast $S E C 18$ gene product in a similar fashion from extracts of whole yeast cells by Western blotting were unsuccessful. Following identification of the Sec18 protein by in vitro translation, the antisera were found to specifically immunoprecipitate the $\left[{ }^{35} \mathrm{~S}\right]$ methionine-labeled in vitro translation product, as well as proteins with the same mobility on SDS-PAGE from extracts of yeast cells labeled with ${ }^{35} \mathrm{SO}_{4}$. A titration curve was generated for the SEC18 antisera, as well as for the other antisera used in this study, by immunoprecipitating ${ }^{35} \mathrm{SO}_{4}$ labeled whole yeast cell extracts $\left(1 \mathrm{OD}_{600}\right.$ unit per sample) with increasing amounts of antiserum. With this information, levels of antiserum were chosen which were in excess over the amount of the labeled proteins to be precipitated along with an amount of protein A-Sepharose CL4B sufficient to bind all the antiserum present, in order to ensure quantitative recovery. Precipitation with this same amount of antiserum against the Sec18p produced in yeast cells containing the SEC 18 gene on a multicopy plasmid with a $2 \mu \mathrm{m}$ origin of replication showed that this level of antiserum was sufficient to precipitate an eightfold excess of labeled SEC18 gene product. Greater amounts of antiserum showed that the total level of Sec18p overproduction was about 20 -fold with the SEC18 gene on a multicopy plasmid.

Northern blot and $5^{\prime}$ and $3^{\prime}$ end mapping. Yeast RNA was prepared by a modification of a previously described procedure (4). Yeast cells were grown in YNB-glucose medium (27) to the mid-log phase. Yeast $\left(50 \mathrm{OD}_{600}\right.$ units) were pelleted, washed with distilled $\mathrm{H}_{2} \mathrm{O}$, and suspended in $2 \mathrm{ml}$

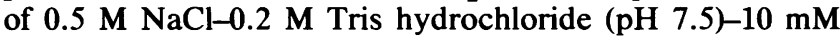
EDTA-1\% SDS. Cells were added to $15-\mathrm{ml}$ polypropylene tubes with $2 \mathrm{~g}$ of acid-washed glass beads and $2 \mathrm{ml}$ of phenol- $\mathrm{CHCl}_{3}$ (1:1 [vol/vol]). Cells were chilled on ice, vortexed extensively, and spun at $12,000 \times g$ at $4^{\circ} \mathrm{C}$ for 10 $\mathrm{min}$ in a rotor (JA-20). The supernatant was reextracted twice more with phenol- $\mathrm{CHCl}_{3}$, and the RNA was precipitated with 2.5 volumes of cold ethanol. Pellets were washed with $70 \%$ ethanol, dried, and redissolved in $10 \mathrm{mM}$ Tris hydrochloride ( $\mathrm{pH} 7.5$ )-1 mM EDTA (TE). RNA recovery was measured by determining the optical density at $260 \mathrm{~nm}$. Sodium acetate was added to $0.3 \mathrm{M}$, ethyl alcohol was added to $70 \%$, and RNA was stored at $-80^{\circ} \mathrm{C}$. Poly $(\mathrm{A})^{+}$RNA was isolated by binding to oligo(dT)-cellulose (Sigma Chemical Co., St. Louis, Mo.) in the presence of $0.5 \mathrm{M} \mathrm{LiCl}$, washing extensively with the high salt buffer, and eluting with TE. RNA was run on formaldehyde- $1 \%$ agarose gels and transferred to GeneScreen (14). Size standards were generated by ${ }^{32} \mathrm{P}$ end-labeling lambda DNA which was cut with EcoRI and HindIII. [ $\left.{ }^{32} \mathrm{P}\right] \mathrm{RNA}$ probes were made by transcribing the noncoding strand of our SEC18 clone in pSP64 with SP6 RNA polymerase with $\left[{ }^{32} \mathrm{P}\right] \mathrm{UTP}$ and were hybridized to the blot as described previously (15).

Mapping at the $5^{\prime}$ end was done by using a ${ }^{32} \mathrm{P}$-end-labeled oligonucleotide (5'-GGGAAATCATTTGGT-3', complementary to bases 681 to 695 of the DNA sequence), which was hybridized to a single-stranded M13-SEC18 subclone and extended with the Klenow fragment of $E$. coli DNA 
polymerase I. The reaction was then digested with HindIII, and the probe was fragment purified on a $6 \mathrm{M}$ urea-5\% acrylamide gel. The probe $\left(10^{5} \mathrm{cpm}\right)$ was hybridized to $25 \mu \mathrm{g}$ of total yeast RNA in $80 \%$ formamide -40 mM PIPES [piperazine- $N, N^{\prime}$-bis(2-ethanesulfonic acid); $\left.\mathrm{pH} 6.8\right]-400 \mathrm{mM}$ NaCl-1 mM EDTA in a total volume of $25 \mu$ l overlaid with $50 \mu$ l of mineral oil. The hybridization reaction mixture was heated at $85^{\circ} \mathrm{C}$ for $5 \mathrm{~min}$ and then incubated at $42^{\circ} \mathrm{C}$ overnight (12). The reaction mixture was diluted with $400 \mu$ l of 50 $\mathrm{mM}$ sodium acetate ( $\mathrm{pH} 5.0$ )-10 $\mathrm{mM} \mathrm{NaCl}^{-1} \mathrm{mM} \mathrm{ZnSO}_{4}$ and digested with $50 \mathrm{U}$ of mung bean nuclease for $1 \mathrm{~h}$ at $37^{\circ} \mathrm{C}(8)$. The reaction was phenol extracted twice and ethanol precipitated with glycogen as a carrier. To identify the size of the digestion products of the hybridization reaction, dideoxy sequencing reactions were carried out with the ${ }^{32} \mathrm{P}$-endlabeled oligonucleotide as the primer and label in the reactions. The sequencing reactions and the digestion products of the hybridization reaction were run on a $6 \%$ sequencing gel.

Mapping at the $3^{\prime}$ end was performed as described above for the mapping of the $5^{\prime}$ end. The probe was a $\left[{ }^{32}\right.$ P]UTPlabeled SP6 RNA polymerase transcript from the HindIII site of our SEC18 clone to the PstI site at position 2235. Hybridization was done as described above for $5^{\prime}$ end mapping, except that overnight incubation was done at $50^{\circ} \mathrm{C}$. Samples were digested with mung bean nuclease as described above and run on a $5 \%$ sequencing gel, with ${ }^{32} \mathrm{P}$-endlabeled lambda phage fragments and undigested probe used as size standards.

In vitro transcription and translation. Yeast in vitro translation extracts were prepared as described previously (31) and treated with micrococcal nuclease. RNA was generated by SP6 RNA polymerase runoff transcription of the minimum complementing subclone of SECI8 cloned in pSP65, using ribonucleotide mixes with and without $0.5 \mathrm{mM}$ $\mathrm{m}^{7} \mathrm{G}\left(5^{\prime}\right) \mathrm{ppp}\left(5^{\prime}\right) \mathrm{G}$ to give a capped mRNA (15). In vitro translation was performed as described previously (31) with 10 to $15 \mu \mathrm{Ci}$ of $\left[{ }^{35} \mathrm{~S}\right]$ methionine per reaction. Translation products were run on SDS-12\% polyacrylamide gels $(5 \%$ stacking gel). Gels were fixed, stained, treated with AutoFlour (National Diagnostics, Somerville, N.J.), and dried before autoradiography on XAR film (Eastman Kodak Co., Rochester, N.Y.).

Immunoprecipitation. Yeast cells were grown to the mid$\log$ phase in a defined medium (10) containing $100 \mu \mathrm{M} \mathrm{SO}$. One $\mathrm{OD}_{600}$ unit of cells per immunoprecipitation sample were pelleted, washed with distilled $\mathrm{H}_{2} \mathrm{O}$, and suspended in $0.5 \mathrm{ml}$ of sulfate-free medium-1 mg of bovine serum albumin per $\mathrm{ml}$. Samples were incubated for $30 \mathrm{~min}$ at $30^{\circ} \mathrm{C}$ with shaking, and 100 to $200 \mu \mathrm{Ci}$ of ${ }^{35} \mathrm{SO}_{4}$ per $\mathrm{OD}_{600}$ unit of cells was added. Cells were labeled for $30 \mathrm{~min}$ at $30^{\circ} \mathrm{C}$ with shaking and unlabeled $\mathrm{SO}_{4}$ was added to a final concentration of $50 \mathrm{mM}$. Labeling or chase was stopped by the addition of trichloroacetic acid to $5 \%$, and samples were put on ice for $20 \mathrm{~min}$. Samples were pelleted in a microfuge for $5 \mathrm{~min}$, and the pellets were washed twice with cold acetone and dried. SDS boiling buffer (1\% SDS, $50 \mathrm{mM}$ Tris [pH 7.5], $1 \mathrm{mM}$ EDTA, $100 \mu \mathrm{l}$ per sample) and glass beads were added, and the samples were vortexed extensively and boiled for $3 \mathrm{~min}$. One milliliter of Tween-IP buffer $(50 \mathrm{mM}$ Tris [pH 7.5], $150 \mathrm{mM} \mathrm{NaCl}, 0.1 \mathrm{mM}$ EDTA, 0.5\% [wt/vol] Tween 20) was added. Samples were vortexed and microfuged for $15 \mathrm{~min}$ in the cold. Supernatant $(0.9 \mathrm{ml})$ was carefully removed, and 1 to $20 \mu$ lof the appropriate antiserum was added. Samples were rocked gently at $4^{\circ} \mathrm{C}$ for $3 \mathrm{~h}$ and $100 \mu \mathrm{l}$ of $3.6 \%(\mathrm{wt} / \mathrm{vol})$ protein A-Sepharose CL4B slurry was added. Samples were rocked for an additional 0.5 $\mathrm{h}$ at $4^{\circ} \mathrm{C}$ and pelleted. The pellets were washed $(1 \mathrm{ml}$ per wash) twice with Tween-IP buffer, twice with Tween-urea buffer (100 mM Tris [pH 7.5], $200 \mathrm{mM} \mathrm{NaCl}, 0.5 \%$ [wt/vol] Tween 20, $2 \mathrm{M}$ urea), once with $1 \% \beta$-mercaptoethanol, and once with $0.1 \%$ SDS. SDS-PAGE sample buffer $(50 \mu \mathrm{l})$ was added, and the samples were boiled for $5 \mathrm{~min}$ before they were loaded onto an SDS-8\% polyacrylamide gel (4\% stacking gel).

Fractionation. Yeast cells to be labeled were pelleted, washed with distilled $\mathrm{H}_{2} \mathrm{O}$, and incubated with $100 \mathrm{mM}$ Tris (pH 8.5)-25 mM dithiothreitol for $5 \mathrm{~min}$ at $30^{\circ} \mathrm{C}$. Cells were pelleted, washed with distilled $\mathrm{H}_{2} \mathrm{O}$, and spheroplasted with $1 \mu \mathrm{g}$ of oxylyticase per $\mathrm{OD}_{600}$ unit of cells in sulfate-free medium, which was adjusted to $\mathrm{pH} 7.5$ and which contained 1.2 M sorbitol for osmotic support (22). Spheroplasts were pelleted gently, washed, suspended with sulfate-free medium ( $\mathrm{pH}$ 5.5) containing 1.2 M sorbitol, and labeled with 50 to $100 \mu \mathrm{Ci}$ of Trans ${ }^{35} \mathrm{~S}$ label per $\mathrm{OD}_{600}$ unit of cells for $30 \mathrm{~min}$ at $30^{\circ} \mathrm{C}$. Cells were pelleted at $500 \times \mathrm{g}$, suspended gently in $100 \mu$ l of $1.2 \mathrm{M}$ sorbitol-100 $\mathrm{mM} \mathrm{KPO}_{4}(\mathrm{pH} \mathrm{7.5)-10} \mathrm{mM}$ EDTA, and lysed by rapid dilution with $1 \mathrm{ml}$ of $0.25 \mathrm{M}$ sucrose-10 mM Tris ( $\mathrm{pH}$ 7.5)-10 mM EDTA-1 mM phenylmethylsulfonyl fluoride-1 $\mathrm{mg}$ of bovine serum albumin per $\mathrm{ml}$. One $\mathrm{OD}_{600}$ unit of the lysed cells was precipitated with trichloroacetic acid for a whole-cell sample. Unlysed cells were pelleted at $2,000 \times g$ for $2 \mathrm{~min}$, and the supernatant was centrifuged at $13,000 \times g$ for $15 \mathrm{~min}$ at $4^{\circ} \mathrm{C}$. Supernatant $(0.8$ $\mathrm{ml}$ ) from the microfuge spin was carefully removed and spun at $100,000 \times g$ in a rotor (Ti70.1). Excess supernatant was removed carefully from the microfuge pellet, which was suspended in $100 \mu$ l of SDS boiling buffer, and boiled for 3 min. The supernatant from the $100,000 \times g$ spin was precipitated with trichloroacetic acid on ice for $20 \mathrm{~min}$, and the $100,000 \times g$ pellet was suspended in $100 \mu$ l of SDS boiling buffer and boiled for $3 \mathrm{~min}$. Samples were immunoprecipitated as described above.

\section{RESULTS}

Characterization and cloning of the SEC18 locus. The sec18-1 mutation in $S$. cerevisiae has been shown to cause a block in the transfer of proteins from the ER to the Golgi complex on a shift to the nonpermissive temperature. This block results in the accumulation of ER, as identified by thin-section electron microscopy $(19,20,25)$. Proteins that transit the secretory pathway also accumulate with modifications that are consistent with their presence inside the ER, that is, with signal sequences removed and only core glycosylation units added to the protein backbone. This block is also reversible. The invertase that accumulated under these conditions has been shown to resume transport through the secretory pathway when it is returned to the permissive temperature (20). The speed with which ER transport is blocked by the sec18-1 mutation is demonstrated in Fig. 1 . Invertase was immunoprecipitated from sec18-1 yeast cells that were grown under various conditions. In Fig. 1, lane 1 shows the size of unglycosylated invertase produced at the permissive temperature in the presence of tunicamycin. To determine the rate of onset of the block in secretory protein traffic in sec $18-1$ mutant yeast cells, we shifted cells to $37^{\circ} \mathrm{C}$ for only $10 \mathrm{~min}$ before they were labeled with ${ }^{35} \mathrm{SO}_{4}$. Under these conditions, invertase accumulated as three distinct bands between 78,000 and 84,000 daltons (Fig. 1, lane 2). These bands corresponded to invertase, which varies in the total number of core oligosaccharide units added to the protein backbone (each core increases the apparent molec- 


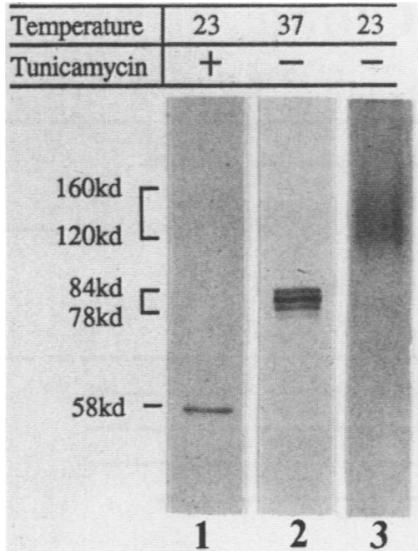

FIG. 1. sec18-1 mutant cells were grown in $100 \mu \mathrm{M} \mathrm{SO}_{4}$ medium with $2 \%$ glucose. Cells were pelleted, washed with distilled $\mathrm{H}_{2} \mathrm{O}$, and suspended in sulfate-free medium with $0.2 \%$ glucose for $30 \mathrm{~min}$ before they were labeled to induce invertase production. Cells were labeled with $0.5 \mathrm{mCi}$ of ${ }^{35} \mathrm{SO}_{4}$ per $\mathrm{ml}$ for $20 \mathrm{~min}$ and chased for 20 min following the addition of $\left(\mathrm{NH}_{4}\right)_{2} \mathrm{SO}_{4}$ to $50 \mathrm{mM}$. kd, Kilodaltons.

ular weight of the protein by 2 to 2.5 kilodaltons). At the permissive temperature (Fig. 1, lane 3), sec $18-1$ mutant cells process the labeled invertase to its highly glycosylated secreted form during passage through the Golgi complex. Thus, the sec18-1 mutation results in a rapid block in secretory protein traffic at some stage after ER translocation and core oligosaccharide modification of secretory proteins.

Based on the results of morphology studies, the rapid and specific block in secretory protein movement, as well as the reversibility of the sec 18 mutant block, we reasoned that the SEC18 gene is likely to code for a function that is directly involved in protein transfer between the ER and Golgi complex. To investigate this function, the $S E C 18$ gene was cloned by complementation of the sec18-1 mutation with a genomic library of yeast DNA fragments in the multicopy vector YEp13 (18). Subcloning and further complementation analysis showed that the complementing activity resides on a 3.0-kb BamHI-HindIII fragment. Because of a lack of restriction sites on one side of the clone, a library of $\mathrm{Bal} 31$ deletion subclones was constructed which extended from either end of the BamHI-HindIII fragment. Complementation analysis with these fragments cloned into the low-copynumber shuttle vector $\mathrm{pSEYC58}$ (CEN4 ARSI) revealed that 500 base pairs (bp) of DNA at the BamHI side of the fragment could be deleted without destroying the complementing activity (Fig. 2B). Deletion of as little as $200 \mathrm{bp}$ from the HindIII side of the fragment was sufficient to destroy complementing activity.

To confirm that our clone carried the authentic SEC18 gene and not a suppressor locus, we substituted the LEU2 gene on a 2.1-kb $\mathrm{HpaI}$ fragment for a 300-bp HpaI fragment in the central region of the clone. A linear fragment with SEC 18 homology at both ends was transformed into the diploid strain SEY6201/SEY5186 (a/ $\alpha$ leu2-3, 112/leu2-3,112 SEC18/sec18-1), and $\mathrm{Leu}^{+}$transformants were selected. Approximately $50 \%$ of the $\mathrm{Leu}^{+}$transformants simultaneously acquired the recessive Ts phenotype, indicating that the SEC18 gene of one homolog was disrupted (23). Tetrad dissections of spores from the Ts diploid strains showed 2:2 segregation of $\mathrm{secl}(\mathrm{Ts}) / \mathrm{Leu}^{-}$: dead $\left(\mathrm{Leu}^{+}\right)$spores per tetrad $(n=7)$. In addition, viable random spores from such diploids were all found to be secl8(Ts)/Leu- (200 haploid spores). These results indicate that our clone maps to the
SEC 18 chromosomal locus and that SECI8 is an essential gene. Examination of the dead spores showed that although many germinated and went through one cell division, none grew beyond the two-cell stage, suggesting that the intracellular pool of $S E C 18$ gene product is sufficient for spore germination but not large enough to sustain vegetative growth.

Further evidence that our clone contained the SECI8 gene was obtained by transforming sec18-1 mutant yeast cells with a yeast integrating plasmid (YIp5 vector) containing a noncomplementing fragment of the SEC18 clone. This plasmid was restricted within the $S E C 18$ DNA to direct integration to the homologous chromosomal region (21). Following selection of $\mathrm{Ura}^{+}$transformants (all of which remained temperature sensitive), genomic DNA was prepared from integrants and restriction digested with an enzyme (EcoRI) which was expected to release the YIp5 vector together with adjacent $S E C 18$ sequences. The resulting DNA fragments were then ligated in dilute solution to recircularize the DNA, transformed into $E$. coli, and selected on the basis of ampicillin resistance. Restriction mapping of the resultant clones showed that they had, in fact, captured the entire sec 18 locus. These clones were shown to contain a functional temperature-sensitive allele of the sec18 gene by transferring the gene to a yeast replicating vector (pSEYC58) and transformation into the SEC18::LEU2/sec18(Ts) diploid strain. These transformants remained temperature sensitive and on sporulation were able to give $\mathrm{Leu}^{+} \mathrm{Ura}^{+}$(Ts) haploids, indicating functional expression of a temperaturesensitive copy of sec 18 from the plasmid. To identify the approximate position of the temperature-sensitive lesion in the sec18-1 mutant gene, restriction fragments were exchanged between the wild-type and sec18(Ts) clones. After transformation into sec18-1 mutant yeast cells, the hybrid gene constructs were scored for whether they encoded a Ts or wild-type form of Sec18p. Based on results of these studies, the sec18-1 mutation was found to unambiguously map to a 351-bp ClaI fragment (Fig. 2A). This placed the Ts mutation within the open reading frame of our $S E C 18$ clone.

DNA sequence of SEC18. The entire 3,042-bp BamHIHindIII SEC18-complementing DNA clone was sequenced by using standard dideoxy sequencing techniques, and the library of Bal 31 deletion subclones described above (Fig. 2C). The sequence (Fig. 3) revealed a 2,271-bp open reading frame which could potentially code for a protein product of 83,903 daltons. A search of the NBRF protein sequence data base showed no significant similarity between the predicted protein sequence and those of other known proteins (13). The position of the start of the smallest complementing subclone was only $35 \mathrm{bp}$ upstream of the first ATG codon of the open reading frame, leaving little room for a SEC18 promoter. Yeast gene promoters normally consist of a TATA sequence element that is usually 40 to 120 bases upstream from the site of transcription initiation and an additional enhancerlike element (upstream activating sequence) 5' to the TATA box (29). Possible TATA sequences are found at positions 516 to 522 and 529 to 533, which are only 10 to $20 \mathrm{bp}$ upstream of the open reading frame. No candidate sequences corresponding to an upstream activating sequence element in the region $5^{\prime}$ to the TATA boxes included in the smallest complementing clone were identified. Two additional ATG codons were present in the open reading frame 54 and 63 bp downstream of the first ATG codon. Combined, this information led us to question whether the transcriptional start point for the gene included the first ATG codon of the open reading frame. 
A)

\section{SEC 18 Gene Clone}

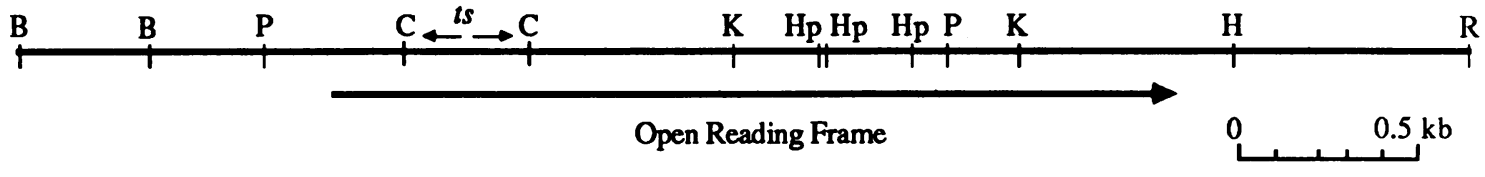

B) Complementation Analysis

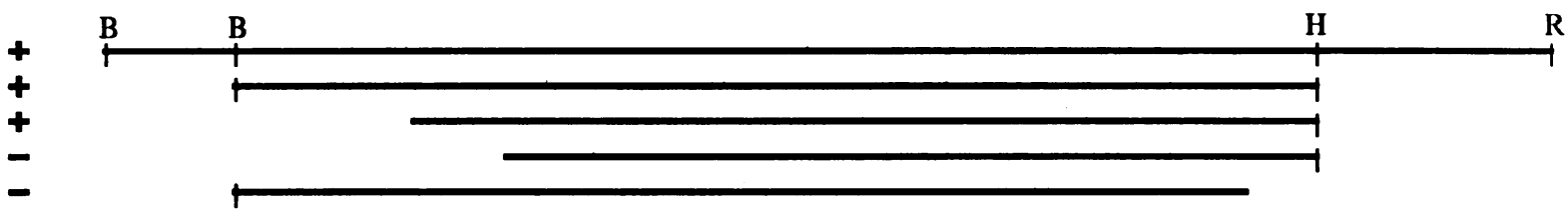

C) Sequencing Strategy

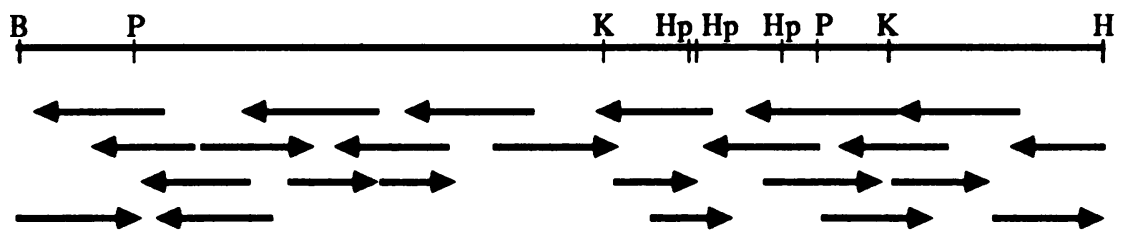

D) mRNA Transcript End-Mapping

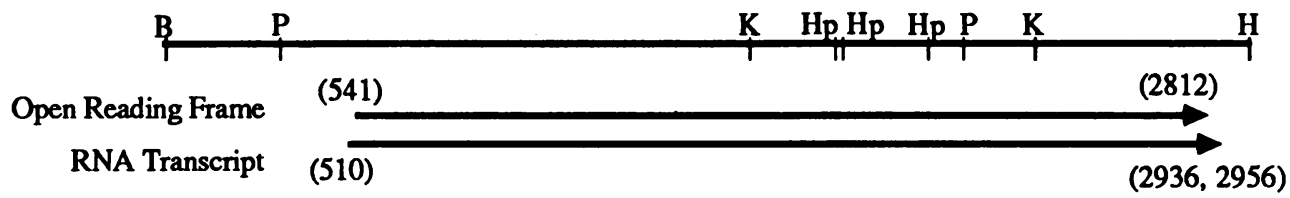

FIG. 2. (A) Restriction map of a SEC18 clone showing the position of the open reading frame as determined by DNA sequencing. Restriction enzyme abbreviations: B, BamHI; P, PstI; K, KpnI ; Hp, HpaI; H, HindIII; C, ClaI; R, EcoRI. The position of the mutation leading to the temperature-sensitive phenotype of sec18-1 is indicated with double arrows. (B) Complementation analysis of $S E C 18$ subclones. Restriction fragments or Bal 31 deletions were cloned into pSEYC58 (CEN4 ARSI URA3) and transformed into strain SEY5186 by LiCl yeast transformation. Transformants were selected for $\mathrm{Ura}^{+}$and tested for growth at 25 and $37^{\circ} \mathrm{C}$. A plus sign indicates temperature-resistant transformants, and a minus sign indicates temperature-sensitive transformants. (C) Sequencing strategy used for DNA sequencing. Each arrow indicates independent subclones obtained by Bal 31 digestion of the 3.0-kb BamHI-HindIII fragment from either end cloned into M13mp19. The entire BamHI-HindIII SEC18 fragment was cloned into M13mp8 and M13mp9 to obtain a sequence from the BamHI site at the $5^{\prime}$ end of the clone and from the HindIII site at the $3^{\prime}$ end of the clone, respectively. (D) Comparison of the results of end mapping of the $S E C 18$ mRNA with the open reading frame of the DNA sequence. Numbers in parentheses represent the positions in the nucleotide sequence. The position of the $5^{\prime}$ end is mapped to \pm 2 nucleotides; the position of the $3^{\prime}$ ends are \pm 15 nucleotides.

Analysis of SEC18 mRNA. Northern blots (Fig. 4A) with single-stranded probes from either strand of the SEC18 clone confirmed that the only transcript from this region of DNA was a poly $(\mathrm{A})^{+}, 2,500$-nucleotide $\mathrm{mRNA}$ in the orientation of the open reading frame seen in the DNA sequence. End mapping experiments of the $5^{\prime}$ end of the SEC 18 transcript were done with a ${ }^{32} \mathrm{P}$-end-labeled single-stranded probe and mung bean nuclease (Fig. 4B). Results of these experiments revealed that there is only one major initiation point for genomic transcription, beginning almost exactly at the position of the start of the smallest complementing subclone. This places our predicted TATA sequences within the transcribed region. Only the DNA which corresponded to the transcribed region appeared to be necessary for complementation of the sec18(Ts) defect. Because other single- and multicopy vectors were used to test complementation of this subclone, it seems unlikely that complementation was due to runon transcripts from other genes on our initial yeast shuttle vector. While aberrant expression of SEC18 on a plasmid vector cannot be ruled out, the observation that the complementing subclone contained so little upstream sequence suggests that sequences which function in transcrip- tion initiation may be located within the transcript or may not be necessary for weak expression. The latter might be explained if only very low levels of $S E C 18$ transcription are required for complementation of the sec18(TS) defect.

End mapping of the $3^{\prime}$ end of the gene (data not shown) showed two major sites of transcription termination at approximately positions 2942 and 2956. Analysis of the sequence downstream from the termination of the open reading frame showed that this region conforms well to the consensus sequence ([T-rich region] . . . TAG . . TAGT/ TATGT ... [AT-rich region]) for yeast termination and polyadenylation (32). The presence of three TAGT-like sequences suggests that these may function as two overlapping pairs of transcription terminators and, thus, lead to the two major sites of termination. Note also that both transcription termination sites were well beyond the TAA codon at position 2812 , which would terminate translation of the open reading frames.

Identification of Sec18p in vitro and in vivo. The protein products of the $S E C 18$ gene were identified by in vitro translation with a yeast translation extract and an SP6 RNA polymerase-generated template RNA corresponding to the 
1 Bga hi

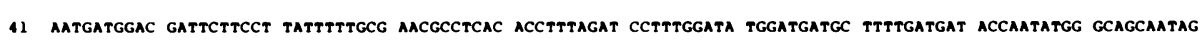

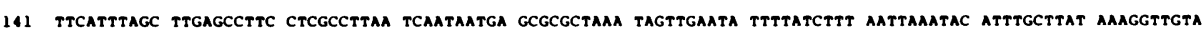

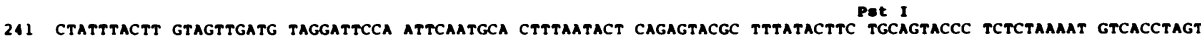

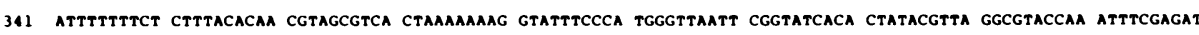

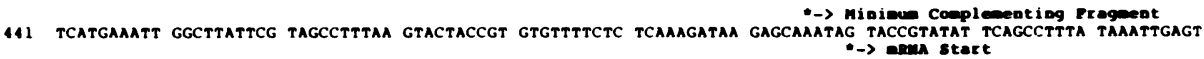

S41 ATG TTC AAG ATA CCT GGT TTT GGA AAA GCT GCT GCA AAT CAT ACT CCA CCA GAT ATG ACA AAC ATG GAT ACC CGT ACA CGC CAT 540

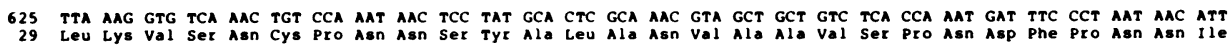

709 TAT ATT ATT ATC GAT AAT TTA TTT GTT TTC ACA ACT AGA CAC TCC AAC GAC ATT CCA CCG GGA ACC ATT GGA TTT AAC GGT AAC

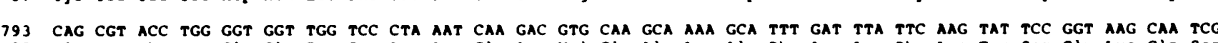

793 CAG CGT ACC TGG GGT GGT TGG TCC CTA AAT CAA GAC GTG CAA GCA AAA GCA TTT GAT TTA TTC AAG TAT TCC GGT AAG CAA TCC
85 GIn Arg thr trp Gly Gly trp Set Leu ASn GIn Asp Val Gln Ala Lys Ala Phe Asp Leu phe Lys tyr Ser Gly Lys GIn Se

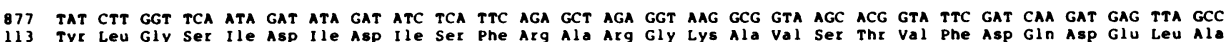

961 AAA CAA TTT GTT CGT TGC TAC GAA TCT CAA ATA TTT TCT CCC ACC CAG TAC CTT ATC ATG GAG TTC CAA GGC CAT TTC TTT GAC

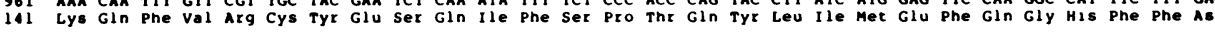

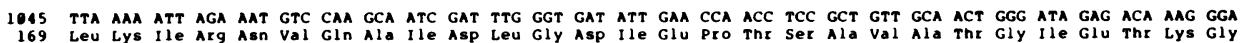

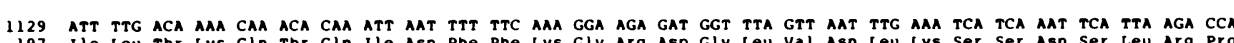

197 lie leu thr Lys Gln thr Gln ile Asn phe phe Lys gly arg asp Gly leu val Asn leu lys Ser Ser Asn Ser Leu Arg pro

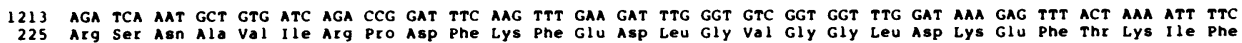

1297 AGA AGA GCG TTT GCA AGT CGA ATC TTT CCT CCT TCA GTT ATA GAA AAA CTG GGT ATT TCT CAT GTT AAA GGT TTG CTA TTG TAC

ter ty

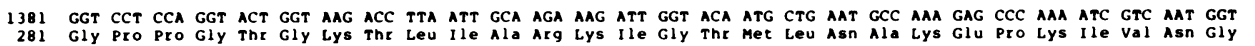

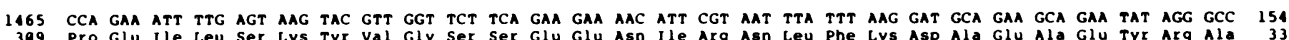

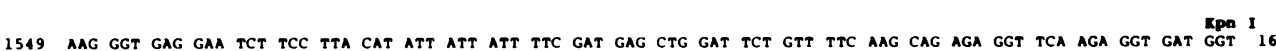

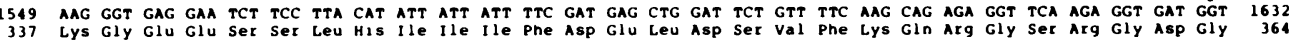

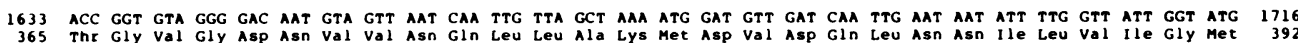

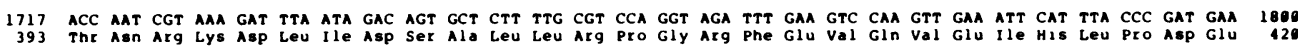

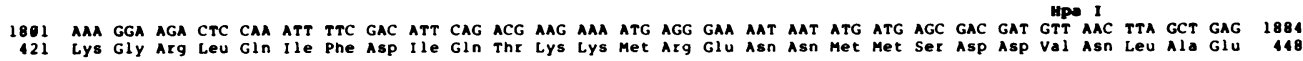

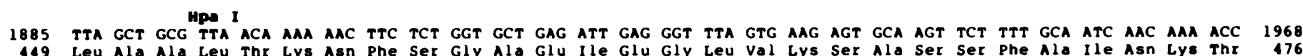

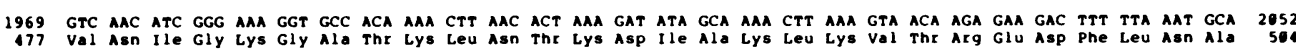

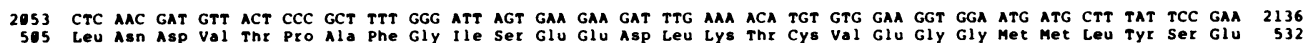

2137 CGA GTT AAC TCA ATA TTC AAG AAC GGA GCC CGT TAC GTC CGC CAA GTT CGC GAG AGT GAT AAA TCC AGG TTA GTA TCT CTA TTA 222

533 Arg Val Asn Ser IIe LeU hys Asn Gly Ala Arg Tyr Val Arg Gln val Arg Glu ser Asp Lys ser Arg Leu val ser LeU LeU 560

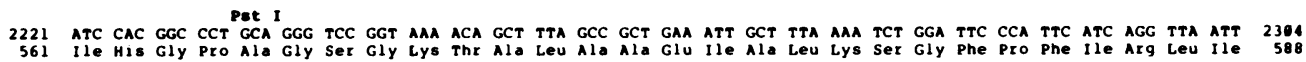

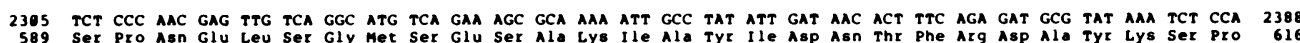

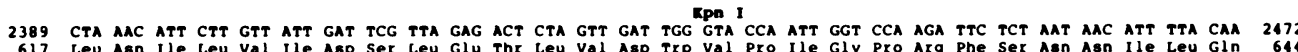

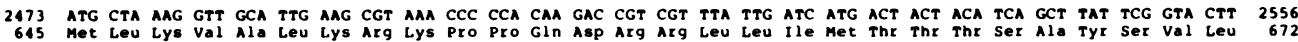

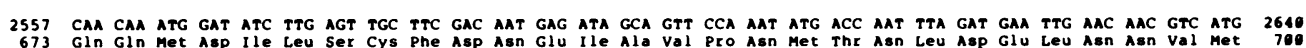

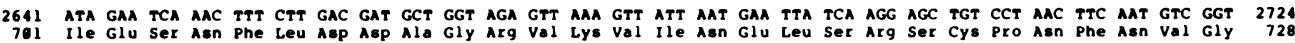

2725 ATT AAA AAG ACC TTG ACC AAC ATT GAA ACC GCA AGG CAC GAT GAA GAT CCC GTG AAC GAG CTT GTT GAG TTG ATG ACC CAA TCC 2808

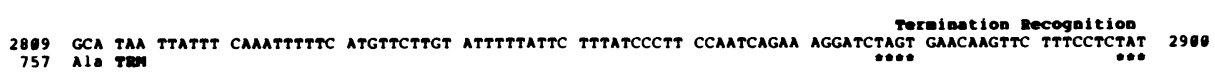

3001 GGTAAMGATG ATAATTTTTC AGTCGCTTTG CCCGAGAAGC

FIG. 3. Nucleotide sequence of SEC18. The nucleotide sequence with translation of the open reading frame. Positions of sites identified by restriction mapping prior to sequencing are indicated in boldface type, as are the positions of initiator methionine codons at the 5 ' end of the open reading frame, the position of the start of the smallest complementing subclone, the position of the transcription start point for $S E C 18$ mRNA, the translation termination codon (TRM), and the transcription recognition sequences and approximate poly(A) addition sites at the $3^{\prime}$ end of the clone. 


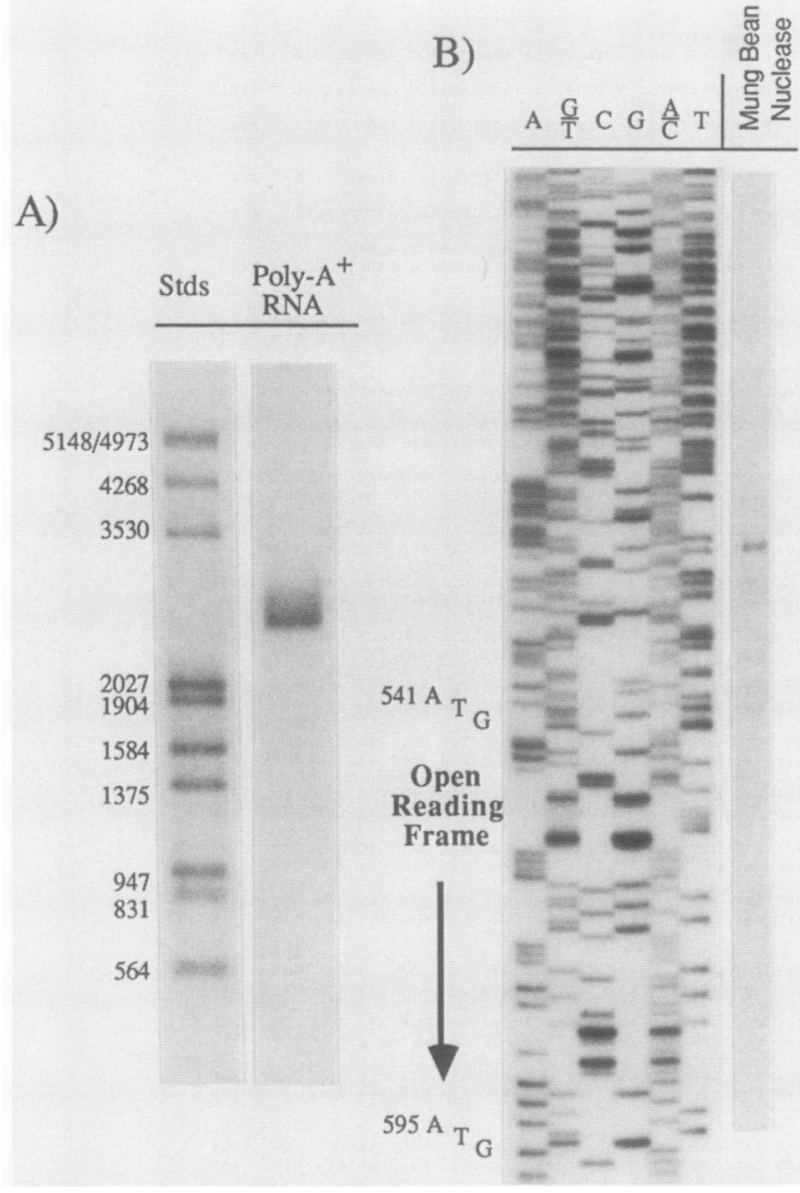

FIG. 4. (A) Northern blot of SEC18 mRNA. Poly(A) ${ }^{+}$RNA (1 $\mu \mathrm{g})$ from mid-log-phase SEY2101 cells was run on a $1 \%$ agaroseformaldehyde gel, transferred to GeneScreen, and probed with an anti-sense $S E C 18\left[{ }^{32} \mathrm{P}\right] \mathrm{RNA}$ that was made with SP6 RNA polymerase. Standards (Stds) were EcoRI- and HindIII-cut lambda DNA that was end labeled by treating it with $\left[\gamma^{-32} \mathrm{P}\right] \mathrm{ATP}$ and T4 polynucleotide kinase. Sizes (in nucleotides) are indicated to the left of the gel. (B) Mapping of the 5' end of SEC18 mRNA. An oligonucleotide complementary to bp 681 to 695 of the DNA sequence was end labeled with ${ }^{32} \mathrm{P}$, hybridized to a single-stranded SEC18-M13mp19 template, and extended with the Klenow fragment to the BamHI site. The single-stranded probe was fragment purified, hybridized to $25 \mu \mathrm{g}$ of total RNA, and digested with mung bean nuclease. The DNA ladder was obtained by deoxy and dideoxy sequencing reactions by using the end-labeled oligo as primer. The positions of the first two ATG codons of the open reading frame of the DNA sequence are indicated to the left of the gel.

minimum complementing SEC18 subclone. Two protein products $(\operatorname{Sec} 18 \mathrm{p})$ were detected, one of 84,000 daltons and one of 82,000 daltons (Fig. 5). The larger product corresponded well to the size predicted for translation of our entire open reading frame. The smaller translation product may have resulted from either premature termination of protein translation or initiation of translation at one of the two ATG codons located at positions 54 and 63 bp downstream from the start of the open reading frame. From the DNA sequence, these smaller open reading frames were predicted to encode proteins of 82,024 or 81,678 daltons. The yeast extract translation system that we used does not normally perform any posttranslational modifications of the protein products such as signal or prosequence cleavages or

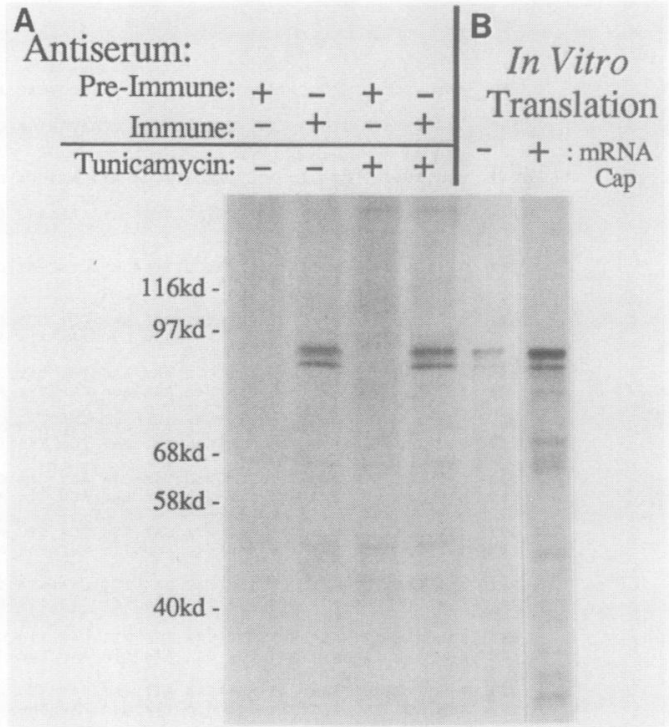

FIG. 5. Identification of Sec18p in vitro and in vivo. (A) Immunoprecipitations of Sec18p from ${ }^{35}$ S-labeled whole-cell yeast extracts done with preimmune or immune serum in the presence or absence of tunicamycin, as indicated. (B) Products of in vitro translation of SP6 RNA polymerase transcripts of the SEC18 open reading frame. RNAs were made with and without a mRNA cap analog $\left[\mathrm{m}^{7} \mathrm{G}\left(5^{\prime}\right) \mathrm{ppp}\left(5^{\prime}\right) \mathrm{G}\right]$ in the transcription reaction, as indicated. Translation of the capped message proceeded with much higher efficiency. kd, Kilodaltons.

the addition of core oligosaccharides which could account for the multiple forms of the proteins that were produced. Transcription by SP6 RNA polymerase also has high fidelity in terms of the site of transcription initiation, so variation in the $5^{\prime}$ end of the RNA template does not seem likely (15).

In order to test whether the protein(s) produced from the $S E C 18$ open reading frame was also produced in vivo, we raised antisera to the $S E C 18$ protein. A gene fusion of the $S E C 18$ open reading frame to the $5^{\prime}$ end of the $E$. coli lacZ gene was generated by ligating random $\mathrm{Bal} 31$ digestions of the 3.0-kb BamHI-HindIII fragment into the vector pORF5 (26) (Fig. 6A). Clones which overproduced $\beta$-galactosidase activity were initially picked by screening on Xgal plates. Plasmids from these clones were screened for inserts corresponding to the $S E C 18$ gene by restriction site analysis. In addition, SDS-PAGE of whole-cell $E$. coli extracts expressing high levels of $\beta$-galactosidase activity were stained with Coomassie blue to visualize the extent of overproduction and to identify the size of the hybrid proteins (Fig. 6B). Western blotting of these gels with $\beta$-galactosidase-specific antibodies confirmed the identity of hybrid protein bands. Several gene fusions were created which overproduced fusion proteins in $E$. coli that were up to 40,000 daltons larger than $\beta$-galactosidase itself. The fusion joints between five of these clones and the $l a c Z$ sequences were determined by DNA sequencing, which confirmed that the large open reading frame of $S E C 18$ was being used. The largest fusion protein was purified by using preparative SDS-PAGE and was injected into rabbits to raise antiserum that was reactive to Sec18p. Antisera were tested initially for reaction to the Sec18- $\beta$-galactosidase fusion protein on Western blots and were later confirmed to react with the in vitro translation products of $S E C 18$.

Immunoprecipitation from extracts of ${ }^{35} \mathrm{~S}$-labeled whole yeast cells with the Sec18p antiserum was able to detect in 


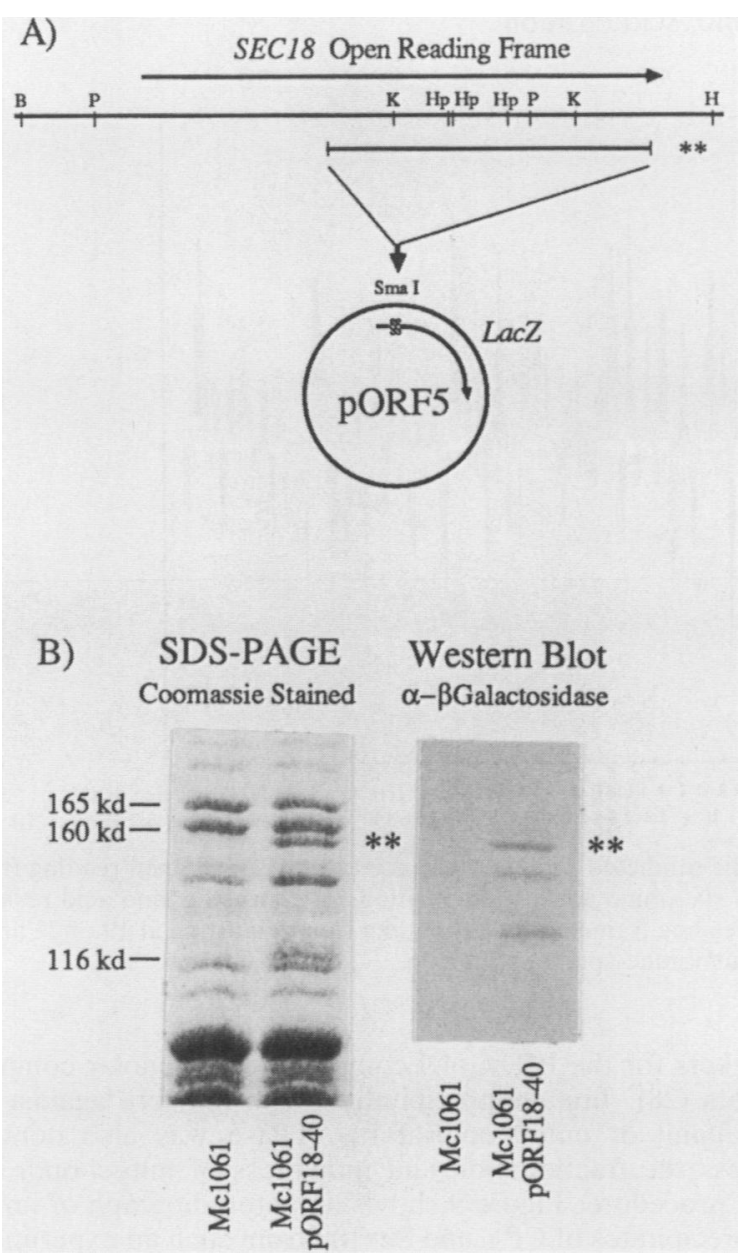

FIG. 6. Production of SECI8-lacZ fusion proteins. (A) Bal 31 digestions of the 3.0-kb BamHI-HindIII fragment were cloned into the SmaI site of pORF5, a lacZ fusion vector in which a EcoRISmaI-BamHI polylinker was inserted at the amino acid at position 7 to interrupt the reading frame of the lacZ gene. The fragment marked with double asterisks is clone pORF18-40, which expressed the largest fusion protein observed. Restriction enzyme abbreviations: B, BamHI; P, PstI; K, KpnI; Hp, HpaI; H, HindIII. (B) Whole-cell extracts of $E$. coli Mc1061, with and without the pORF18-40 fusion plasmid, were run on SDS-polyacrylamide gels. A gel stained with Coomassie blue G-250 is shown on the left, and on the right is a Western blot of a gel identical to that shown on the left whose proteins were transferred to nitrocellulose by Western blot and probed with anti- $\beta$-galactosidase antisera. The largest fusion protein is marked with double asterisks. kd, Kilodaltons.

vivo production of the putative $S E C 18$ gene products. The in vivo forms of Sec18p were identical in size to those seen by in vitro translation (Fig. 5). Tunicamycin, which inhibits $\mathrm{N}$-linked glycosylation, had no effect on the size of the in vivo proteins that were observed, even though potential sites for glycosylation were present in the predicted amino acid sequence at amino acid positions 13, 36, 455, 474, and 689 . This suggests that Sec18p is not translocated across the ER membrane into the secretory pathway, and thus, it never comes into contact with the oligosaccharide transferase enzyme. This was further supported by the hydrophobicity profile for the predicted Sec18p sequence (Fig. 7), which showed no evidence for a characteristic hydrophobic signal sequence at the amino terminus of either the full-length protein or a protein whose translation began at one of the two downstream ATG codons at the $5^{\prime}$ end of the open reading frame. In addition, the hydrophobicity profile did not show any internal regions which would be predicted to span a membrane or function as internal signal sequences. These data are most consistent with the fact that Sec18p remained in the cell cytoplasm. However, these results do not exclude the association of Sec18p with the cytoplasmic face of an intracellular organelle membrane.

The two forms of Sec18p seen in vivo also could have resulted from a posttranslational processing event other than glycosylation. To address this question, yeast cells were pulse-labeled for $20 \mathrm{~min}$ with ${ }^{35} \mathrm{SO}_{4}$ and chased for various times following the addition of excess cold $\mathrm{SO}_{4}$. Whole-cell extracts were immunoprecipitated with antisera directed against both Sec18p and CPY, a vacuolar protease which undergoes processing in the ER, Golgi complex, and vacuole to give forms which can be distinguished on SDS-polyacrylamide gels (28). The results (Fig. 8) indicated that while CPY is processed normally with a half-time of approximately 5 min, the two forms of Sec18p are maintained in a constant ratio. This was true for chase periods of up to $2 \mathrm{~h}$ (data not shown). Thus, the two forms of Sec18p do not appear to result from posttranslational processing of the larger form into the smaller form or vice versa. It appears that messages containing the entire open reading frame lead directly to the production of two forms of the same protein. It is reasonable to propose that the two forms arise from translation that is initiated at different points in the open reading frame of the mRNA.

Results of this study indicate that Sec18p represents a relatively minor fraction total protein production in yeast cells. From quantitation of the relative levels of production of Sec18p and CPY by densitometry, we estimate that Sec18p is produced at only $1 / 5$ th to $1 / 10$ th of the level of CPY. Twentyfold overproduction of Sec18p was observed in cells harboring the $S E C 18$ gene on a multicopy plasmid (pSEY8). This suggests that Secl8 is expressed constitutively and is subject to simple gene dosage control. Experiments looking at the production of Sec18p from the mutant sec 18-I(Ts) allele show that the temperature-sensitive defect does not result from a decrease in Sec18p expression. In addition, the temperature-sensitive forms of the protein appear to show the same stability at the nonpermissive temperature as wild-type proteins do in pulse-chase labeling experiments (data not shown).

Intracellular location of Sec18p. Our data predict that Sec18p is probably a cytoplasmic protein. To determine this directly, we used cell fractionation techniques with differential centrifugations to separate yeast cells into membraneenclosed and cytoplasmic compartments. Because of its role in transport between the ER and Golgi complex, we were especially interested to see whether Sec18p might be associated with these compartments. A procedure giving gentle osmotic lysis was developed which appeared to maintain the integrity of small organelles such as mitochondria, ER, and the Golgi complex. Cells were spheroplasted extensively before they were labeled, and then they were washed and labeled with Trans ${ }^{35} \mathrm{~S}$ label in the presence of full osmotic support (1.2 M sorbitol). To lyse the cells osmotically, cells were pelleted gently, suspended in a small volume of buffer with full osmotic support, and then quickly diluted in a buffer with partial osmotic support (0.25 $\mathrm{M}$ sucrose). After an initial low-speed spin to pellet any unlysed cells, the cleared lysate was centrifuged sequentially in a microfuge $(13,000 \times$ $g$ for $15 \mathrm{~min})$ and a ultracentrifuge $(100,000 \times g$ for $30 \mathrm{~min})$. 


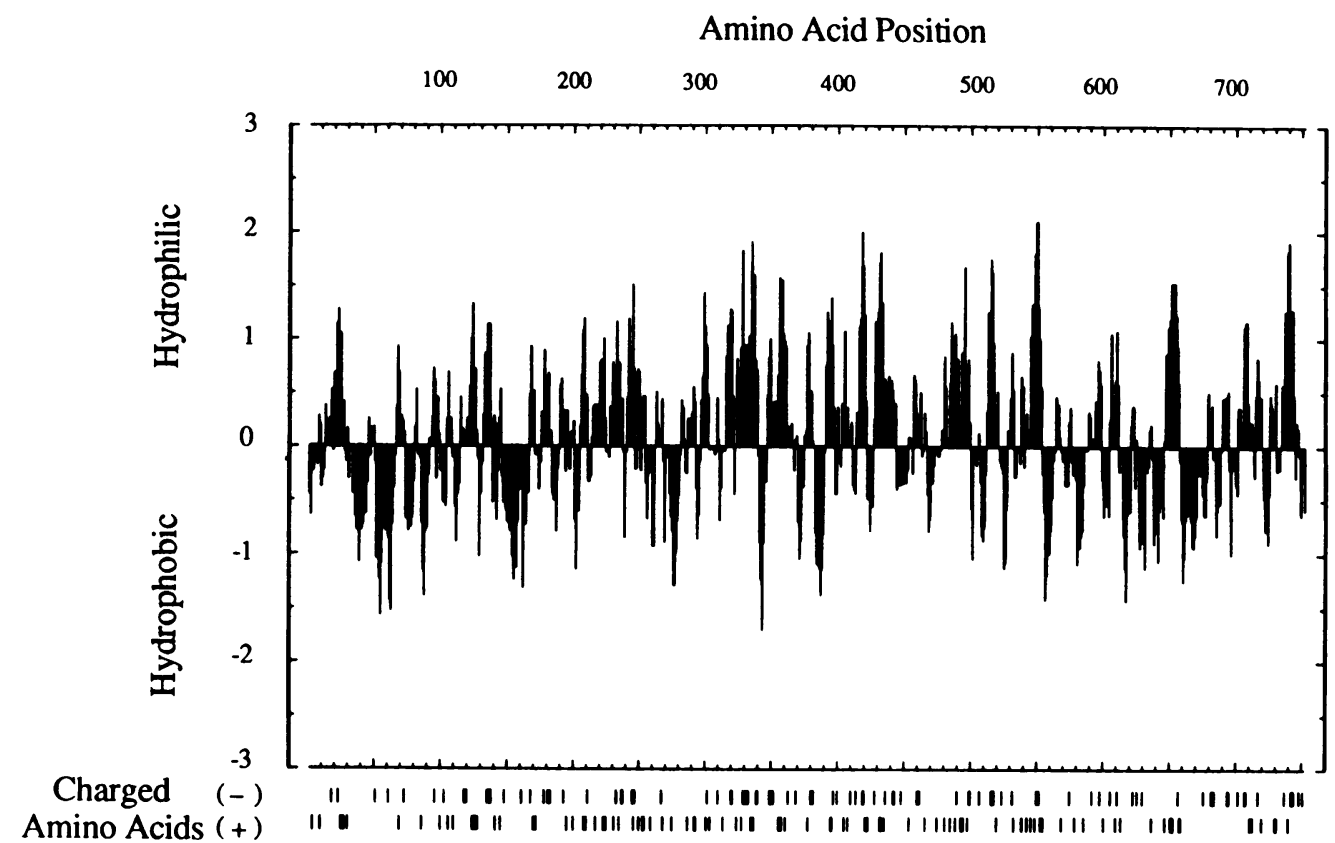

FIG. 7. Hydrophobicity analysis of Sec18p. A hydrophobicity profile of the predicted protein sequence of the SEC18 open reading frame was calculated by using the values of Hopp and Woods (9) and a window of six amino acids. The positions of charged amino acid residues are indicated by the tics at the bottom of the figure. Neither the entire open reading frame nor open reading frames starting at 19 or 21 amino acids into the protein sequence revealed a satisfactory signal sequence or membrane-spanning domain.

Judging from trichloroacetic acid-precipitable counts, only 30 to $50 \%$ of cells were lysed by this procedure. However, no enhancement of any particular form of the markers used was observed, which suggests that the cleared lysate is representative of the contents of the cell.

Fractions were immunoprecipitated with Sec18p antisera under conditions of antibody excess to ensure that comparisons of the level of Sec18p present in the various fractions were valid. Likewise, intermediates in the maturation of CPY were monitored by using CPY-specific antisera to give

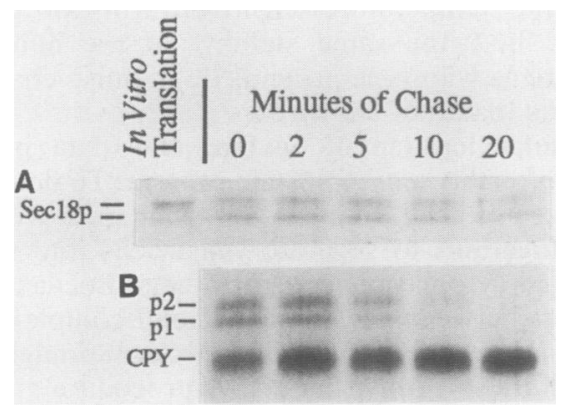

FIG. 8. Pulse-chase labeling of Sec18p and CPY. Yeast cells (strain SEY2101; $1 \mathrm{OD}_{600}$ unit per lane) were labeled for $30 \mathrm{~min}$ with ${ }^{35} \mathrm{SO}_{4}$ at $30^{\circ} \mathrm{C}$ and chased for the indicated times following the addition of $\left(\mathrm{NH}_{4}\right)_{2} \mathrm{SO}_{4}$ to a final concentration of $50 \mathrm{mM}$. Labeling was stopped by the addition of trichloroacetic acid to $5 \%$, and cell extracts were immunoprecipitated simultaneously with saturating amounts of both Sec18p and CPY antisera. (A) Two forms of Sec18p were not posttranslationally modified into a single species; (B) p1 (ER) and p2(Golgi complex) forms of CPY were chased posttranslationally into the mature vacuolar form. In panel $A$ exposure of the gel was 2 times longer than that in panel B. From densitometry of the bands, we estimate that $\mathrm{Sec} 18$ is produced at approximately $1 /$ 10th the level of CPY. markers for the ER, Golgi complex, and vacuolar compartments (28). Immunoprecipitation with antisera against the $\beta$-subunit of mitochondrial $F_{1}$-ATPase was also done to assess the fractionation and intactness of mitochondria in this procedure. Figure 9 shows an autoradiograph of immunoprecipitates of CPY and Sec18p from such an experiment, which is quantitated in Table 1 . The $\mathrm{p} 1$ and $\mathrm{p} 2$ forms of CPY, which should be localized within the ER and Golgi complex, respectively, were mainly present $(80 \%)$ in the $13,000 \times g$ pellet. A small amount of p1 and p2 (20\%) was found in the $100,000 \times g$ pellet fraction, perhaps because of some fragmentation of these compartments or the material present in small vesicles in transit between secretory organelles. Greater than $95 \%$ of the $\beta$-subunit of mitochondrial $F_{1}$ ATPase was also pelleted in a microfuge. These results indicate that organelles such as ER, Golgi complex, and

TABLE 1. Quantitation of cell centrifugation ${ }^{a}$

\begin{tabular}{lccc}
\hline \multirow{2}{*}{ Fraction } & \multicolumn{3}{c}{$\%$ of fraction in ${ }^{b}:$} \\
\cline { 2 - 4 } & \multicolumn{2}{c}{ Pellet from: } & $\begin{array}{c}\text { Supernatant } \\
\text { from } \begin{array}{c}100,000 \\
\times g\end{array}\end{array}$ \\
\cline { 2 - 4 } & $\begin{array}{c}13,000 \times g \\
\text { centrifugation }\end{array}$ & $\begin{array}{c}100,000 \times g \\
\text { centrifugation }\end{array}$ & $\begin{array}{c}\text { centrifugation } \\
\text { cenn }\end{array}$ \\
\hline Sec18p & $<1$ & 44 & 56 \\
p1 and p2 CPY & 80 & 20 & $<1$ \\
Mature CPY & $<5$ & $<1$ & $>95$ \\
Mitochondrial F & $>95$ & $<1$ & $<5$ \\
\hline
\end{tabular}

a Quantitation was done by scanning autoradiographs on a laser densitometer (2202; LKB Instruments, Inc., Rockville, Md.) and integration with a program (GelScan; LKB).

$b$ Percentages represent the amount present in a given fraction divided by the total of all three fractions. In all cases, the quantitative sum of all three fractions was within $10 \%$ of the quantitation of a similar whole-cell lysate sample. Samples which were $<5$ or $<1 \%$ were either too faint for accurate quantitation or difficult to resolve because of the presence of contaminating background bands. 

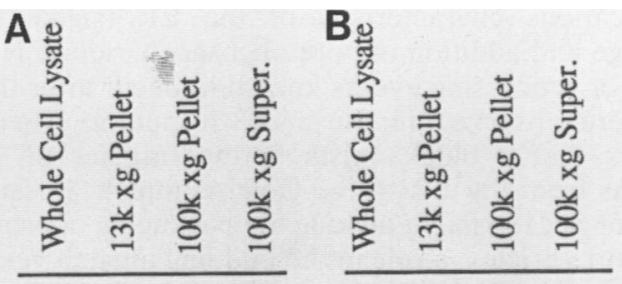

$116 \mathrm{kd}^{-}$

\author{
$97 \mathrm{kd}^{-}$ \\ $\operatorname{Sec} 18 \mathrm{p}=$ \\ $68 \mathrm{kd}-$ \\ $40 \mathrm{kd}-$
}

were represented. The fact that mature CPY was not associated with the high-speed pellet fraction indicates that the Sec18p found in the pellet was not the result of nonspecific trapping. The data suggest that Sec18p does not interact directly with ER or the Golgi complex within the cell, or does so only very transiently. The presence of significant amounts of Sec18p in the $100,000 \times g$ pellet fraction, along with a small proportion of the ER and Golgi complex forms of CPY, suggests that Sec18p may associate with small vesicles in transit from the ER to the Golgi complex. It is also possible that Sec18p binds to some large macromolecular complex such as the cytoskeletal network which could be pelleted at the higher $g$ force. The possibility remains that the association of Sec18p with the $100,000 \times g$ pellet may be an artifact caused by aggregation of the protein or binding to membrane fragments. Nevertheless, the association of Sec18p with the high-speed pellet may provide a clue to the functional role of Sec18 within the cell. Note also that there was not a preferential association of one or the other form of Sec18p with the pellet fraction, which suggests that the two protein forms may be functionally equivalent.

\section{DISCUSSION}

As a first step in understanding the role of the yeast $S E C 18$ gene product in secretory protein transport between the ER and the Golgi complex, we cloned and sequenced the gene. A single 3.0-kb DNA fragment was isolated that complemented the temperature-sensitive defect exhibited by secl81 mutant yeast cells. This DNA segment mapped genetically to the SEC18 locus. RNA probes derived from the cloned segment detected one major 2,500-nucleotide poly $(A)^{+}$ mRNA on Northern blots (Fig. 4A). Consistent with this, the major open reading frame $(2,271 \mathrm{bp})$ in the $S E C 18$ clone was predicted to encode a protein of 84 kilodaltons. Somewhat surprisingly, two protein products of this open reading frame were observed both from in vitro translation extracts programmed with SEC18 mRNA and from in vivo ${ }^{35} \mathrm{~S}$-labeled yeast cell extracts (Fig. 5). Disruption of this open reading frame indicates that the function of Sec18p is essential for cell viability. Spores containing a disrupted SEC18 gene were able to germinate but only underwent, at most, one round of cell division in the absence of $S E C 18$ expression.

Several aspects of $S E C 18$ gene expression were novel and unexpected. First, sequences upstream from the site of transcription initiation did not appear to be necessary for SEC18 expression. A subclone which contained only five nucleotides preceding the start point of transcription was sufficient for the expression of adequate levels of Sec18p for the complementation of the sec18-1 mutation. Complementation with this subclone was observed when several different high- and low-copy-number yeast shuttle vectors were used, suggesting that aberrant expression of this subclone in a particular plasmid context is not the cause of the observed complementation.

Second, there were two sequences just upstream of the open reading frame, TATATT at bases 516 to 522 and TATAAA at 529 to 535 , which could possibly function as TATA elements for transcriptional control. Yet, these sequences were actually within the transcribed region itself rather than at the normal position that TATA elements usually occupy 40 to $120 \mathrm{bp} 5^{\prime}$ of the site of transcription initiation (29). This, along with the fact that the transcribed region alone appeared to be sufficient for gene expression, raises the possibility that $S E C 18$ promoter elements may function from within the gene itself. Alternatively, these 
TATA elements formed part of a cryptic promoter leading to expression of the minimum complementing fragment.

Third, the $S E C 18$ gene produced two proteins from transcripts that appeared to start at a single site. Other cases of the expression of multiple forms of protein from a single yeast gene have been observed, such as the production of cytoplasmic and secreted forms of invertase from the yeast SUC2 gene (2). However, these were caused by multiple sites of transcription initiation leading to messages which had different AUG codons of the open reading frame at their $5^{\prime}$ ends. There is a precedent for translation initiating at multiple AUG codons in a yeast mRNA. The GCN4 gene of $S$. cerevisiae, whose protein product controls the transcription of a large number of amino acid biosynthesis genes, uses translation initiation at multiple AUG codons in the mRNA as a translational control of its expression (17). Four short open reading frames of an AUG codon followed by two to three codons are present in an $\sim 600$ nucleotide leader region of the GCN4 mRNA and act to inhibit the translation of GCN4 under nonstarvation conditions (17). In contrast, SEC 18 appeared to have only one major class of mRNA with a short $5^{\prime}$-untranslated leader and a set of three AUG codons early in the mRNA that were all in frame with the major open reading frame of the gene, yet two forms of the same protein with different sizes were produced (Fig. 4 and 5). The two forms of the protein did not appear to be the result of posttranslational processing events (Fig. 8). The size of the smaller protein product corresponded well to the predicted size of translation products initiated from AUGs that were 19 or 21 codons downstream of the first AUG codon of the open reading frame, leading us to suggest that the smaller protein product arises from translation initiating at one of these downstream codons. In vitro mutagenesis of the different AUG codons in SEC18 should reveal whether translation indeed starts at more than one site or whether another mechanism is responsible for the multiple forms of protein being produced. In addition, such in vitro mutagenesis should permit one to test whether the two Sec18 proteins are functionally equivalent. It is tempting to speculate that the two isoforms of Sec18p could have different functional roles in directing secretory protein traffic.

The intracellular location of Sec18p was analyzed to gain insight into the functional role that Sec18 plays in the secretory pathway. The predicted amino acid sequences of Sec18 proteins did not indicate any targeting signal which would allow Sec18p to be translocated across the ER membrane. The conclusion that Sec18p remains in the cytoplasm was reinforced by the observation that Sec18p was not modified with core oligosaccharides (Fig. 5), a function which is carried out within the ER, even though potential sites for $\mathrm{N}$-linked glycosylation are present in the amino acid sequence. Results of cellular fractionation experiments by an osmotic lysis procedure, which was able to maintain the integrity of organelles such as mitochondria, ER, and the Golgi complex, indicated that Sec18p is not tightly associated with the bulk of ER or the Golgi complex (Fig. 9). However, centrifugation at higher $g$ forces revealed a distribution of Sec18p between the pellet and soluble fractions. This observation suggests that $\mathrm{Sec} 18 \mathrm{p}$ may be associated with small vesicles or a macromolecular complex that is important in intracellular secretory protein transport.

The phenotype of sec18-1 mutant yeast cells suggests a direct role for Sec18p in the transport of secretory proteins between the ER and the Golgi complex. At the nonpermissive temperature, there was a rapid accumulation of newly synthesized secretory proteins which underwent all of the modifications characteristic of the ER (signal sequence cleavage and addition of core oligosaccharides). No modification or processing events known to occur after that of the ER were observed in the sec18-1 mutant. Therefore, it appears that a block exists in the transfer of secretory proteins from the ER to the Golgi complex. Possible functions for Sec18p might include the packaging of proteins into transport vesicles, a role in the budding of such vesicles, the transport of vesicles to the target organelle, recognition or fusion of these vesicles with the Golgi complex, or the recycling of transport components back to the ER. The cytoplasmic location of Sec18p rules out any direct role in the sorting and selection of proteins from the lumen of the ER for transport to the Golgi complex. Our data, which show an association of Sec18p with a high-speed pellet fraction, suggest that Sec18p may function in the formation of small transport vesicles at the ER or in their transport and targeting to Golgi complex membranes. The recent development of efficient in vitro transport assays for ER to Golgi complex protein traffic (1) may provide a means to examine directly the functional role of Sec18p in this critical interorganelle transport event, potentially in both yeast and mammalian reconstituted systems.

\section{ACKNOWLEDGMENTS}

We thank Elizabeth Greyhack for help with in vitro translation, Lois Banta and Jean Edens for electron microscopy, and Michael Clark for expertise and help with microscopy in general. We also thank Shawn Westway for assistance with BIONET and Cathy Elkins for typing the manuscript. We thank Randy Schekman for support, especially in the early stages of cloning SECI8, and for continued interest throughout.

This study was supported by Public Health Service grant GM32703 from the National Institutes of Health (to S.D.E.). K.A.E. was supported in part by National Research Service Award 1 T32 GM07616 from the National Institute of General Medical Sciences. S.D.E. is a Presidential Young Investigator supported by grant DCB-8451633 from the National Science Foundation.

\section{LITERATURE CITED}

1. Beckers, C. J. M., D. S. Keller, and W. E. Balch. 1987. Semi-intact cells permeable to macromolecules: use in reconstitution of protein transport from the endoplasmic reticulum to the Golgi complex. Cell 50:523-534.

2. Carlson, M., and D. Botstein. 1982. Two differentially regulated mRNAs with different 5 ' ends encode secreted and intracellular forms of yeast invertase. Cell 28:145-154.

3. Casadaban, M. J., and S. N. Cohen. 1980. Analysis of gene control signals by DNA fusion and cloning in E. coli. J. Mol. Biol. 138:179-207.

4. Elder, R. T., E. Y. Loh, and R. W. Davis. 1983. RNA from the yeast transposable element $T y l$ has both ends in the direct repeats, a structure similar to retrovirus RNA. Proc. Natl. Acad. Sci. USA 80:2432-2436.

5. Emr, S. D., I. Schauer, W. Hansen, P. Esmon, and R. Schekman. 1984. Invertase $\beta$-galactosidase hybrid proteins fail to be transported form the endoplasmic reticulum in Saccharomyces cerevisiae. Mol. Cell. Biol. 4:2347-2355.

6. Emr, S. D., R. Schekman, M. C. Flessel, and J. Thorner. 1983. An MF $\alpha$-SUC2 ( $\alpha$ factor-invertase) gene fusion for study of protein localization and gene expression in yeast. Proc. Natl. Acad. Sci. USA 80:7080-7084.

7. Esmon, B., P. Novick, and R. Schekman. 1981. Compartmentalized assembly of oligosaccharides on exported glycoproteins in yeast. Cell 25:451-460.

8. Green, M. R., and R. G. Roeder. 1980 . Definition of a novel promoter for the major adenovirus-associated virus mRNA. Cell 22:231-242.

9. Hopp, T., and K. R. Woods. 1981. Prediction of protein antigenic determinants from amino acid sequences. Proc. Natl. 
Acad. Sci. USA 78:3824-3828.

10. Klionsky, D., L. M. Banta, and S. D. Emr. 1988. Intracellular sorting and processing of a yeast vacuolar hydrolase: proteinase A propeptide contains vacuolar targeting information. Mol. Cell. Biol. 8:2105-2116.

11. Laemmli, U. K. 1970. Cleavage of structural proteins during the assembly of the head of bacteriophage T4. Nature (London) 227:680-685.

12. Lee, J. J., F. J. Calzone, R. J. Britten, R. C. Angerer, and E. H. Davidson. 1986. Activation of sea urchin actin genes during embryogenesis: measurement of transcript accumulation from five different genes in Strongylocentrotus purpuratus. J. Mol. Biol. 188:173-183.

13. Lipman, D. J., and W. R. Pearson. 1985. Rapid and sensitive protein similarity searches. Science 227:1435-1441.

14. Maniatis, T., E. F. Fritsch, and J. Sambrook. 1982. Molecular cloning: a laboratory manual. Cold Spring Harbor Laboratory, Cold Spring Harbor, N.Y.

15. Melton, D., P. Kreig, T. Rebaglianti, T. Maniatis, T. Kinn, and M. Green. 1984. Efficient in vitro synthesis of biologically active RNA and RNA hybridization probes from plasmids containing an SP6 promoter. Nucleic Acids Res. 18:7035-7056.

16. Miller, J. 1972. Experiments in molecular genetics. Cold Spring Harbor Laboratory, Cold Spring Harbor, N.Y.

17. Mueller, P. P., and A. G. Hinnebusch. 1986. Multiple upstream AUG codons mediate translational control of $G C N 4$. Cell 45: 201-207.

18. Nasmyth, K. A., and K. Tatchell. 1980. The structure of transposable yeast mating type loci. Cell 19:753-764.

19. Novick, P., S. Ferro, and R. Schekman. Order of events in the yeast secretory pathway. Cell 25:461-469.

20. Novick, P., C. Field, and R. Schekman. 1980. Identification of 23 complementation groups required for post-translational events in the yeast secretory pathway. Cell 21:205-215.

21. Orr-Weaver, T. L., J. W. Szostak, and R. J. Rothstein. 1983. Genetic application of yeast transformation with linear and gapped plasmids. Methods Enzymol. 101:228-245.

22. Reid, G. A. 1983. Pulse-labeling of yeast cells and spheroplasts. Methods Enzymol. 97:324-329.

23. Rothstein, R. J. 1983. One-step gene disruption in yeast. Methods Enzymol. 101:202-211.

24. Sanger, F., S. Nicklen, and A. R. Coulson. 1977. DNA sequencing with chain-terminating inhibitors. Proc. Natl. Acad. Sci. USA 74:5463-5467.

25. Schekman, R., and P. Novick. 1982. The secretory process and yeast cell-surface assembly, p. 361-398. In J. N. Strathern, E. W. Jones, and J. R. Broach (ed.), The molecular biology of the yeast Saccharomyces: metabolism and gene expression. Cold Spring Harbor Laboratory, Cold Spring Harbor, N.Y.

26. Schultz, J., T. J. Silhavy, M. L. Berman, N. Fiil, and S. D. Emr. 1982. A previously unidentified gene in the $s p c$ operon of Escherichia coli $\mathrm{K} 12$ specifies a component of the protein export machinery. Cell 31:227-235.

27. Sherman, F., G. R. Fink, and L. W. Lawrence. 1979. Methods in yeast genetics: a laboratory manual. Cold Spring Harbor Laboratory, Cold Spring Harbor, N.Y.

28. Stevens, T., B. Esmon, and R. Schekman. 1982. Early stages in the yeast secretory pathway are required for transport of carboxypeptidase $Y$ to the vacuole. Cell 30:439-448.

29. Struhl, K. 1987. Promoters, activator proteins, and the mechanism of transcriptional initiation in yeast. Cell 49:295-297.

30. Towbin, H., T. Staehelin, and J. Gordon. 1979. Electrophoretic transfer of proteins from polyacrylamide gels to nitrocellulose sheets: procedure and some applications. Proc. Natl. Acad. Sci. USA 76:4350-4354.

31. Tuite, M. F., J. Plesset, K. Moldave, and C. S. McLaughlin. 1980. Faithful and efficient translation of homologous and heterologous mRNAs in an mRNA-dependent cell-free system from Saccharomyces cerevisiae. J. Biol. Chem. 255:8761-8766.

32. Zaret, K. S., and F. Sherman. 1982. DNA sequence required for efficient transcription termination in yeast. Cell 28:563-573. 